\begin{tabular}{rr} 
çağdaş & Yaratıcı Drama Dergisi 2016, 11(1), 17-32 \\
drama & www.yader.org \\
\hline
\end{tabular}

\title{
Hikâye Temelli Yaratıcı Drama Etkinliklerinin Dört Yaş Grubu Çocukların İfade Edici Dil Gelişimine Etkisi*
}

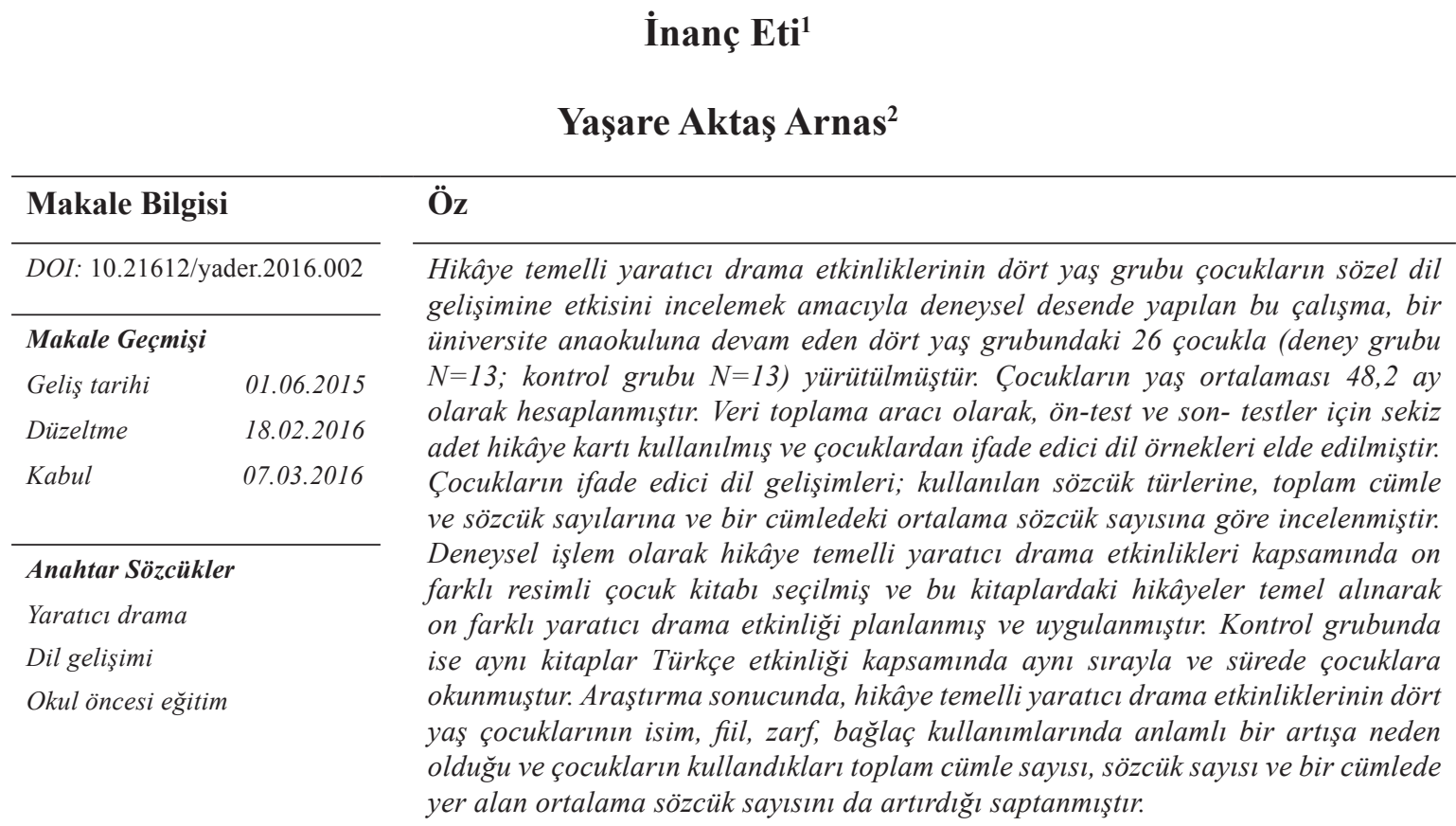

\section{The Effect of Story-Based Creative Drama Activities on Four-Year-Old Childrens' Expressive Language Development}

\begin{tabular}{lr}
\multicolumn{2}{l}{ Article Info } \\
\hline DOI: $10.21612 /$ yader.2016.002 \\
\hline Article History & \\
Received & 01.06 .2015 \\
Revised & 18.02 .2016 \\
Accepted & 07.03 .2016
\end{tabular}

Keywords

Creative drama

Language development

Early childhood education

\begin{abstract}
The aim of this study is to investigate the effect of story-based creative drama activities on oral language development of four-year-old children. The study which is designed as an experimental research is conducted with 26 children who are enrolled in a university day-care center. Data is collected through eight story cards for pre-test and post-tests. Ten children books are selected and used for story-based creative drama activities for the experimental procedure. In the control group, the same children books were just read by the researcher in language activities. The results of this research show that story-based creative drama activities are provided statistically significant increase in the rate of noun, verb, adverb and conjunction usage in children oral language. Besides, the average count of sentences, sentence length and word count in a sentence are also increased.
\end{abstract}

Bu çalışma MEB Özel Doğaç Yaratıcı Drama Liderliği Projesi’nden geliştirilmiştir.

2 Dr., Çukurova Üniversitesi Eğitim Fakültesi İlköğretim Bölümü, Okul Öncesi Eğitimi ABD, E-posta: ieti@cu.edu.tr, inanceti@ yahoo.com

3 Prof. Dr., Çukurova Üniversitesi Eğitim Fakültesi İlköğretim Bölümü, Okul Öncesi Eğitimi ABD, E-posta: yasare@cu.edu.tr 


\section{Giriş}

Erken çocukluk döneminde dil, iletişimi sağlayan en güçlü araçlardan biridir. Çocuk dil ile duygu ve düşüncelerini aktarırken yaratıcı hayal gücü de kişiliğinin oluşumuna yardım eder (Macrory, 2010). Bu dönemde dil becerileri açısından büyük değişimler görülmektedir (Cook ve Cook, 2005). İki yaşından itibaren çocuklar kelimeleri birleştirmeye (Guasti, 2002), dört yaşına geldiklerinde ortalama üç-dört kelimeden oluşan cümleler kurmaya ve altı-yedi yaşlarına geldiklerinde ise yetişkin konuşmalarına benzer şekilde konuşmaya başlarlar (Yazgan İnanç, Bilgin ve Atıcı Kılıç, 2008). Bununla birlikte dil gelişiminin temelleri okul öncesi dönemde atılıyor olsa da bu süreç sonraki yıllarda da devaml11ık göstermektedir (Hoff, 2005).

Çocukların başlarda sadece aile içinde kurdukları iletişim, okul öncesi sınıflarda diğer çocuklar ve yetişkinlerin de katılımıyla artmaktadır. Böylece çocuklar gün geçtikçe genişleyen çevreleri ile birlikte sahip oldukları dili daha fazla kullanma gereksinimi duymaktadırlar (Aktaş Arnas, Cömertpay ve Sofu, 2007). Okul öncesi eğitim kurumlarında zenginleştirilmiş dil ortamları yaratmak, çocukların dili edinmeleri ve dili yaratıcı bir şekilde kullanmaları için çok önemlidir (Güven ve Bal, 2000). Okul öncesi eğitim programında yer alan oyun etkinliklerinin yanı sıra Türkçe ve drama etkinlikleri de çocukların dili kullanma sıklığını artıran ve dil gelişimlerini destekleyen etkinlikler arasındadır (MEB, 2013).

Dili öğrenme sürecinde diğer çocuklarla etkileşim çok önemlidir. Oyun, çocukların başka yerlerden öğrendikleri şeyleri pratik yapmaları ve aynı zamanda birbirlerinden dili öğrenmeleri için zengin firsatlar sağlar (Ervin Tripp, 1991). Bruner, oyun ve dil arasındaki ilişkiyi "dilin en karmaşık gramer ve pragmatik formları ilk olarak oyun etkinliklerinde ortaya çıkmaktadır" şeklinde ifade etmektedir (Akt: Weisberg, Zosh, Hirsh-Pasek ve Golinkoff, 2013). Çocukların oyun içinde iletişimi çok güçlüdür. Özellikle sosyo-dramatik oyunlarda çocuklar birlikte oyunu kurgular ve oyunun çatısını oluştururlar. Kurguladıkları oyunu arkadaşlarına anlatırlar ve planlarını açıklarlar, oyunun çatısı içinde rolleri paylaşır ve eylemleri koordine ederler. Tüm bu süreçte çocuklar birlikte yorum yapar ve tartışırlar. Çocuklar oyun içinde diğer çocuklarla etkileşimde bulunduğunda oyun dışında diğerleri ile etkileşimde bulunurken kullandığı dilden daha ileri düzeyde dil kalıplarını kullanırlar. Oyun, çocuğu bu konuda cesaretlendirir. Yani çocuklar oyun oynarken günlük hayatta kullandığından daha karmaşık bir dil yapısı kullanmaktadırlar (Weisberg ve ark., 2013).

Sosyo-dramatik oyun gibi, yaratıcı drama etkinlikleri de doğası gereği rol oynama ve sözel iletişime dayalı etkinliklerdir (Mages, 2008). Özünde oyunsu süreçleri barındıran yaratıcı drama etkinliklerinin (Adıgüzel, 1994), çocukların dil gelişimlerini destekleyen ve onların kendi dil potansiyellerini kullanmalarına cesaret veren bir etkinlik olduğu düşünülmektedir. Yaratıcı drama, grup etkileşimleri yaratması sayesinde çocuklara başkalarını dinleme, kendisini sözel olarak ifade etme, sahip olduğu dili kullanma gibi sayısız dil firsatları sunmaktadır (Mages, 2008; Maley ve Duff, 2006). Kısacası yaratıcı drama etkinlikleri çocuklara etkileşim, iletişim ve tartışma firsatı sunduğu için onları dil gelişimleri açısından desteklemektedir (Szecsi, 2008). Yapılan çalışmalar yaratıcı dramanın küçük yaştaki çocukların gelişimlerini desteklemek için bir araç olarak kullanılabileceğini gösterirken (Mages, 2008; Furman, 2000) çocukların dil gelişimlerine de pozitif ve güçlü bir etkisi olduğunu göstermektedir (Podlozny, 2000; Kardash ve Wright, 1987).

Yaratıcı drama çeşitlerinden biri olan hikâye temelli drama çalışmaları da çocukların dil gelişimini destekleyen etkinlikler arasında sayılabilir. Hikâye temelli drama (hikâye draması) çalışmaları hikâyeyi temel alan doğaçlamalar ile dramatizasyon (bir hikâyeyi sahnelemeyi içeren) 
çalışmalarından oluşmaktadır. Hikâye temelli drama, önceden belirlenmiş hikâyelerden yola çıkarak yapılan canlandırmaları ifade etmektedir (Laurin, 2010). Hikâye temelli drama, çocukların hikâyeyi keşfetmesi için yeni bir yoldur ve çocuklar mevcut olan bir hikâyenin parçası olmaktan çok hoşlanırlar (Kelin, 2007). Çünkü hikâye kitapları çocuklara geniş ve büyüleyici bir dünyaya giriş fırsatı sunarak onları bulundukları yer ve zamandan farklı, başka dünyalara götürür. Aynı zamanda çocuklara hikayeler hakkında konuşmaları, tartışmaları ve hayal güçlerini kullanmaları için uygun firsatlar sağlar. Hikâyeler çocukların konuşma ve dinleme becerilerini geliştirebilir (Kelin, 2007; Riley \& Reedy, 2003). Çocuklara hikâyeler okumak onların yeni kelimelerle karşılaşmaları ve yeni kelimeler öğrenmeleri için en iyi yollardan biridir (Elley, 1989; McCaslin, 2006). Örneğin, Isbell, Sobol, Lindauer ve Lowrance (2004), yaptıkları deneysel çalışmada çocuklara hikâye anlatmanın ve hikâye kitabı okumanın üç-beş yaş çocukların ifade edici dil gelişimlerinde olumlu değişimler yaptığını bulmuşlardır. Umek, Fekonja, Kranjc ve Musek (2003) da sistematik ve düzenli olarak çocuk kitapları okumanın dört-altı yaş çocukların dil gelişimlerine katkı sağladığını bulmuşlardır. Çocuklara okunan hikâyelerin yanı sıra çocukların hikâye temelli drama ile hikâyelerde geçen diyalogları canlandırmaları onlara öğrendikleri bu kelimeleri kullanmaları ve pratik yapmaları için de firsatlar sunmaktadır (McCaslin, 2006). Baldwin ve Hendy (2008)'e göre, çocuklar yaratıcı drama sürecinde oynadıkları roller aracılığıyla bilişsel ve duyuşsal anlamda dâhil oldukları hikâyeyi yaşarken etkin katılımcılardır. Aynı zamanda karşılıklı etkileşim içinde ve ortaklaşa olarak hikâye yazan ve hikâye anlatan kişilerdir. Zafeiriadou (2009)'un da belirttiği gibi iyi bir hikâye kitabı bütün bir yaratıcı drama etkinliği için yeterli olabilir.

Okul öncesi dönemde yaratıcı drama ve dil gelişimi arasındaki ilişkiyi incelen pek çok çalışma yaratıcı drama ve dil arasında güçlü bir bağ olduğunu göstermektedir (Uyar,1995; Aral, Gülen, Alisinanoğlu, Aktaş, Başar ve Köksal, 1997; Solmaz, 1997; Cömertpay, 2006; Çakır, 2008; Koç, 2009). Örneğin, Koç (2009), altı yaş grubu çocuklarla yaptığı deneysel çalışmada, drama yönteminin kullanıldığı gruptaki çocukların dil gelişimlerinin kontrol grubundaki çocuklardan daha çok ilerlediğini belirlemiştir. Benzer bir çalışmada Cömertpay (2006), yaratıcı drama etkinliklerine katılan gruptaki çocukların kontrol grubundaki çocuklara göre dil gelişimlerinde önemli artışlar olduğunu bulmuşlardır. Niedermeyer ve Oliver (1972) anaokulu ve birinci sınıf devam eden çocukların dil gelişimleri üzerine drama etkinliklerinin pozitif katkıları olduğunu bulmuşlardır. Benzer şekilde Koç (2009) da drama eğitimi alan gruptaki çocukların dil puanları lehine anlamlı sonuçlar bulmuştur.

Yaratıcı drama ve çocukların dil gelişimleri arasındaki ilişkiyi inceleyen bu çalışmalar irdelendiğinde, çalışmaların genel olarak beş - altı yaş grubu çocukların dil gelişimleri üzerinde yoğunlaştığı ve beş yaşından küçük çocukların ihmal edildiği görülmektedir. Oysaki Riley ve Parker (2005)' 'n da belirttiği gibi “çocuklarda tümce edinimi beş aşamada gerçekleşmekte ve son aşama dört yaşı kapsamaktadır» (Akt. Baştürk, 2013). Bu bilgiden yola çıkıldığında çocukların dil gelişimlerini desteklemek için dört yaşta yapılacak dil etkinlikleri büyük önem kazanmaktadır. Ancak alan yazın incelendiğinde, okul öncesi dönemde çocukların dil gelişimlerine yönelik yapılmış yaratıcı drama çalışmalarının daha çok beş - altı yaş grubu üzerine odaklandığı görülmektedir (Uyar, 1995; Solmaz, 1997; Cömertpay, 2006; Aktaş Arnas, Cömertpay ve Sofu, 2007; Çakır, 2008; Koç, 2009). Bu bağlamda dört yaş grubu çocukları çalışma grubuna alan çalışmaya rastlanmamıştır.

Yine alan yazında hikâyelerin ve hikâye temelli drama çalışmalarının çocukların dil gelişiminde önemli katkıları olduğu belirtilmesine karşın çocukların dil gelişimleri ve hikâye temelli drama arasındaki ilişkiyi inceleyen sadece birkaç çalışmaya rastlanmıştır (Çakır, 2008; O’Neill 
2008). Bu çalışmalardan birinde O’Neill (2008) hikâye temelli drama etkinliklerinin okul öncesi özel eğitime ihtiyacı olan çocukların dil, sosyal ve oyun becerilerine olumlu katkı sağladığını bulmuştur.

Hem yapılan çalışmalarda dört yaş grubu çocukların ihmal edilmiş olması hem de hikâye temelli etkinliklere çok fazla yer verilmemiş olması bu çalışmanın temel problemini oluşturmaktadır. Hikâyelerden yola çıkılarak hikâye temelli drama çalışmalarına yer verilen bu çalışmada, doğaçlama ve rol oynama gibi temel drama tekniklerinin yanı sıra diğer drama tekniklerine de yer verilmiştir. $\mathrm{Bu}$ şekilde çocuklara dili kullanmaları için daha zengin ve yaratıcı firsatlar sunulmuştur.

Buradan hareketle, bu çalışmanın genel amacı, hikâye temelli yaratıcı drama etkinliklerinin dört yaş grubu çocukların ifade edici dil gelişimine etkisini incelemektir. Bu genel amaç doğrultusunda, deney ve kontrol gruplarında kullanılan

a. sözcük türlerine ilişkin grup içi ve gruplar arası anlamlı farklılık var mıdır?

b. toplam cümle sayısı açısından grup içi ve gruplar arası sözcük türlerine ilişkin anlamli farklilık var midır?

c. toplam sözcük sayısı açısından grup içi ve gruplar arası sözcük türlerine ilişkin anlamlı farklılık var midir?

d. ortalama sözcük sayıları açısından grup içi ve gruplar arası sözcük türlerine ilişkin anlamlı farklılık var midır?

sorularına yanıt aranmıştır.

\section{Yöntem}

\section{Çalışma Grubu}

$\mathrm{Bu}$ araştırmanın çalışma grubunu, bir üniversiteye bağlı anaokuluna devam eden dört yaş grubundaki 26 çocuk oluşturmaktadır (deney grubu $\mathrm{N}=13$; kontrol grubu $\mathrm{N}=13$ ). Deney ve kontrol gruplarını oluşturmak amacıyla, anaokulunun iki sınıfı tesadüfî örneklem yöntemi ile belirlenmiştir. Deney grubundaki çocukların altısı kız, yedisi erkek çocuktan oluşurken bu çocukların yaş ortalaması $\mathrm{x}=48,2$ ay $($ min. $=46 a y-\max .=53 \mathrm{ay})$ olarak hesaplanmıştır. Kontrol grubundaki çocukların ise sekizi kız, beşi erkek çocuk olup yaş ortalamaları $\mathrm{x}=48,2$ aydır $(\min .=45$ ay - max. $=52$ ay). Her iki grupta yer alan çocukların aileleri orta sosyo-ekonomik düzeyden olup, hemen hepsinin anne ya da babası üniversitede memur pozisyonunda çalışmaktadır.

\section{Veri Toplama Araçları}

\section{Hikâye kartları}

Araştırmada çocukların ifade edici dil gelişimlerinin belirlenmesi için deney ve kontrol gruplarında hem ön-test hem de son-testte veri toplama aracı olarak hikâye kartları kullanılmıştır. Çocuklardan kendilerine gösterilen hikâye kartlarındaki resimlere bakarak bir hikâye üretmeleri istenmiştir. Bu amaçla "Meraklı Sarı Yumak" (Oğuzkan, 2000) adlı resimli çocuk kitabının sekiz sayfası kesilerek 21,5x20 cm. boyutlarındaki kartonlara yapıştııılmış ve jelâtin ile kaplanarak hikâye kartları oluşturulmuştur. Hikâye kartları için kitap seçiminde, çalışmanın yapıldığ sınıfların kitap merkezlerinde bulunmayan ve okul öncesi eğitim dönemine uygun olduğu belirtilen kitaplar arasından bir okul öncesinde çocuk edebiyatı uzmanın görüşleri temel alınmıştır. Hikaye kartları yine uzman görüşü doğrultusunda 16 sayfalık kitaptan, her resimde ana karakterin yer aldığ 1 ve bir olay örüntüsü içerecek şekilde sekiz ayrı resimden oluşmuştur. 


\section{Verilerin Toplanması}

Veri toplama sürecine başlamadan önce araştırmacı çalışma grubundaki çocuklarla tanışmak amacıyla onların eğitim süreçlerine üç ayrı günde dâhil olmuştur. Veriler yaratıcı drama uygulamaları öncesinde ve sonrasında olmak üzere iki kez toplanmıştır. Verilerin toplanması aşamasında anaokulunun boş bir sınıfinda her bir çocuk ile bireysel olarak çalışılmıştır. Bu amaçla çocuklar tek tek sınıfından alınarak çalışmanın yapılacağı diğer sınıfa getirilmiştir. Araştırmacı ve çocuk karşılıklı oturmuşlardır. Araştırmacı, çocuğun önüne hikâye kartlarını koyarak "Şimdi bu kartlara bakarak bana bir hikâye anlatmanı isteyeceğim.” yönergesini vermiş ve çocuğu hikâye anlatmaya cesaretlendirmiştir. Hikâye kartları çocuğun önüne hikâyedeki sıraya uygun olarak konulmuştur. Çocuktan her bir resimde gördüklerini anlatması istenmiştir. Çocuk her bir kartla ilişkili olarak hikâyeyi anlatırken araştırmacı zaman zaman çocuğa “Başka neler olmuş? Peki ya daha sonra?” gibi sorular sorarak çocuğun ifadelerini genişletmesini sağlamıştır. Veri toplama süreci ortalama olarak her bir çocuk için 10 dakika sürmüştür.

\section{Uygulama Süreci}

\section{Deney Grubu İle Yapılan Hikâye Temelli Yaratıcı Drama Uygulamaları}

Yaratıcı drama uygulamalarına ön test verilerinin toplanmasından sonra başlanmıştır. Uygulamanın başlangıç aşamasında araştırmaya dâhil edilen çocukların daha önce herhangi bir yaratıcı drama geçmişi bulunmadığından çocukların yaratıcı drama etkinliklerine, lidere, gruba ve mekâna alışmaları için temel hazırlık çalışmaları ile başlanmıştır. Bu temel hazırlık çalışmaları, araştırmacılardan biri tarafindan deney grubundaki çocuklarla ilk iki hafta, haftada üç gün daha sonra haftada iki gün, olmak üzere toplam sekiz oturumdan oluşmuştur. Bu süreçte oyunlar, iletişim ve güven çalışmaları ile temel düzeyde rol oynama ve doğaçlama çalışmalarına yer verilmiştir.

Yapılan temel hazırlık çalışmasından sonra haftada iki kez olmak üzere beş hafta boyunca çocukların dil edinimlerini destekleyen hikâye temelli yaratıcı drama etkinliklerine yer verilmiştir. $\mathrm{Bu}$ amaçla on farklı resimli çocuk kitabı seçilmiş ve bu kitaplardan yola çıkılarak on yaratıcı drama etkinliği planlanmıştır. Yaratıcı drama oturumlarında kullanılan resimli kitaplar, kurgusunda dramatik çatışmaları barındıran kitaplar olup bu kitaplara ve kitaplardan yola çıkarak hazırlanan yaratıcı drama planlarına, eğitimde yaratıcı drama alanında uzman kişiler tarafından incelenerek karar verilmiştir. Ek.2'de deneysel işlem sırasında kullanılan resimli çocuk kitaplarının tam listesi sunulmuştur.

Hazırlanan yaratıcı drama planlarının tamamında hazırlık-1sınma, canlandırma ve değerlendirme aşamalarına yer verilmiştir. Canlandırma aşamasında teknik olarak okul öncesi eğitime uygun olduğu düşünülen rol oynama, tüm grup doğaçlama, ikili eş-zamanlı doğaçlama, küçük grup doğaçlama, öğretmenin role girmesi, sözsüz canlandırma, donuk imge, düşünce izleme ve dramatizasyon teknikleri kullanılarak sürecin zenginleştirilmesi amaçlanmıştır. Çocuklarla yapılan her bir drama oturumu ortalama 45-60 dakika arasında sürmüştür.

\section{Kontrol Grubu ile Yapılan Uygulamalar}

Kontrol grubundaki çocuklarla yaratıcı drama etkinliklerini uygulayan araştırmacı tarafından ilk dört hafta oyunlar oynanmıştır. Bu oyunlar deney grubuyla oynanan oyunlarla aynı oyunlar olup içerik bakımından yine sınıf içi kaynaşma ve etkileşimi temel alan hareketli ve dinlendirici oyunlardır. Daha sonra deney grubunda yaratıcı drama etkinliklerinde kullanılan aynı on hikâye kitabı, yine 
aynı sırayla haftada iki kez toplam beş hafta içinde kontrol grubundaki çocuklara Türkçe etkinliği kapsamında okunmuştur. Okunan kitapların konusuyla ve kurgusuyla ilgili çocuklara etkinlik sonrasında betimleyici sorular sorulmuştur. Kontrol grubuna yapılan uygulama deney grubuyla aynı tarihler arasında ve aynı sırayla gerçekleştirilmiştir.

\section{Verilerin Analizi}

Çocukların ifade edici dil gelişimlerine ilişkin veriler, çocuklara gösterilen hikâye kartlarından yola çıkarak anlattıkları hikâyeler aracılığıyla toplanmıştır. Çocukların hikâye kartlarından yola çıkarak oluşturdukları dil örnekleri ses kayıt cihazına kaydedilmiş, daha sonra ses kayıtları bilgisayar ortamına aktarılmış ve yazılı dökümü yapılarak analize hazırlanmıştır. Çocukların dil örnekleri sözcük türleri, kullanılan toplam sözcük sayısı, cümle sayısı ve bir cümlede kullanılan ortalama sözcük sayısı ölçütleri açısından analiz edilmiştir.

Elde edilen dil örneği metinleri, araştırmanın tutarlılı̆̆1 açısından bir araştırmacı ve beş yıllık iş tecrübesi olan bir Türkçe öğretmeni tarafından analiz edilmiştir. Her iki kişi de çocukların anlattıkları hikâyelerden elde edilen yazılı metinleri sözcük türleri açısından incelenmiş ve her bir sözcük türüne göre gruplandırmalar yapılmıştır. Bunun yanı sıra, çocukların kullandıkları toplam cümle sayıları, sözcük sayıları ve bir cümlede kullanılan ortalama sözcük sayıları hesaplanmıştır.

Elde edilen sayısal veriler, SPSS 16.0 istatistik programı ile analiz edilmiştir. Yaratıcı drama etkinliklerinin çocukların ifade edici dil gelişimine anlamlı bir etkisinin olup olmadığını belirlemek için, non-parametrik testlerden, Wilcoxon İşaretli Sıralar testi uygulanmıştır. Bu test, az denekli gruplar içi fark puanlarının anlamlılığını test etmek için uygulanmaktadır (Büyüköztürk, 2012). Ayrıca grupların fark puanları arasında anlamlı bir farkın olup olmadığını belirlemek için de MannWhitney U testi uygulanmıştır. Bu test ilişkisiz iki gruptan elde edilen puanların anlamlı bir şekilde birbirinden farklılaşıp farklılaşmadığını test etmek için uygulanmaktadır (Büyüköztürk, 2012). Elde edilen istatistiksel analiz sonuçları bulgular başlığı altında sunulmuştur.

\section{Bulgular ve Yorum}

Bu bölümde, çalışma verilerinin analizi sonucunda elde edilen bulgular araştırma alt amaçları doğrultusunda sunulmuş ve yorumlanmıştır.

\section{Sözcük Türlerine İlişkin Bulgular}

Çocuklardan elde edilen veriler sözcük türlerine göre gruplandırıldığında çocukların, çoğunlukla isim, fiil, sıfat, zamir, fiilimsi, zarf ve bağlaçları kullandıkları görüldüğünden analizler bu sözcük türleri üzerinden yapılmıştır. Bunun yanı sıra çocukların ender olarak edat ve ünlemleri kullandıkları belirlendiğinden, bulgularda edat ve ünlemlere yer verilmemiştir.

Bulgular incelendiğinde aslında her iki grubun da son-test ortalamalarında ön-test ortalamalarına göre bir artış olduğu görülmektedir. Bu oluşan farkın anlamlılığını test etmek için her grubun kendi içerisindeki ön-test ve son-test ortalamaları Wilcoxon İşaretli Siralar Testi ile analiz edilmiş ve elde edilen bulgular Tablo 1 ve Tablo 2' de sunulmuştur.

Tablo 1'de deney grubundaki çocukların her bir sözcük grubuna ait ön-test ve son-test sonuçlarına ilişkin betimsel bulguları ve analizler verilmiştir. 
Tablo 1. Deney Grubundaki Çocukların Sözcük Türlerini Kullanımlarına İlişkin Ön test-Son test Betimsel Bulguları ve Wilcoxon İşaretli Stralar Testi Sonuçları

\section{Deney Grubu}

\begin{tabular}{l|cccc|cccc|cc}
\hline \multirow{2}{*}{ Sözcük Türleri } & \multicolumn{4}{|c|}{ Ön-Test } & \multicolumn{4}{c|}{ Son-Test } & \multicolumn{2}{c}{ Wilcoxon } \\
\cline { 2 - 12 } & $\mathrm{X}$ & $\mathrm{Sd}$ & Max. & Min. & $\mathrm{X}$ & $\mathrm{Sd}$ & Max. & Min. & $\mathrm{Z}$ & $\mathrm{P}$ \\
\hline İsim & 12.85 & 9.14 & 36 & 4 & 29.46 & 15.65 & 63 & 9 & 3.11 & .002 \\
\hline Fiil & 11.23 & 5.60 & 28 & 6 & 23.69 & 13.13 & 59 & 9 & 3.06 & .002 \\
\hline Fiilimsi & 2.38 & 3.99 & 14 & 0 & 5.77 & 6.52 & 17 & 0 & 2.67 & .007 \\
\hline Zamir & 4.00 & 4.73 & 14 & 0 & 4.69 & 3.35 & 10 & 0 & .53 & .592 \\
\hline Sifat & 1.46 & 2.22 & 8 & 0 & 5.00 & 4.04 & 12 & 0 & 2.94 & .003 \\
\hline Zarf & 2.62 & 3.12 & 10 & 0 & 10.31 & 7.07 & 23 & 0 & 2.99 & .003 \\
\hline Bağlaç & 2.92 & 3.84 & 11 & 0 & 9.92 & 7.30 & 24 & 0 & 2.75 & .006 \\
\hline
\end{tabular}

Deney grubundaki çocukların hikâye temelli yaratıcı drama etkinlikleri öncesi ve sonrasında yapılan ön-test ve son-test sonuçları incelendiğinde, sözcük türleri açısından çocukların son-test puan ortalamalarında önemli bir artış olduğu saptanmıştır. Yaratıcı drama etkinlikleri öncesinde çocuklar anlattıkları hikâyelerde ortalama olarak 12.85 isim, 11.23 fiil, 2.38 filimsi, 1.46 sifat, 2.62 zarf ve 2.92 bağlaca yer verirken, drama etkinlikleri sonrasında sırasıyla 29.46 isim, 23.69 fiil, 5.77 fiilimsi, 5.00 sifat, 10.31 zarf ve 9.92 bağlaca yer vermişlerdir.

Deney grubundaki çocukların ön-test ve son-test ortalamalarındaki artışın istatistiksel olarak anlamlı olup olmadığı yapılan Wilcoxon İşaretli Sıralar Testi analiziyle belirlenmiştir. Buna göre, deney grubundaki çocukların cümle içerisinde kullandıkları isim, fiil, fiilimsi, sıfat, zarf ve bağlaçlar açısından ön test ve son test puan ortalamaları arasında istatistiksel olarak anlamlı bir farklılık bulunurken $\left(\mathrm{z}_{\text {isim }}=3.11 ; \mathrm{z}_{\text {fiil }}=3.06 ; \mathrm{z}_{\text {filimsi }}=2.67 ; \mathrm{z}_{\text {sffat }}=2.94 ; \mathrm{z}_{\text {zarf }}=2.99 ; \mathrm{z}_{\text {bağlaç }}=2.75 ; \mathrm{p}<.05 ; \mathrm{N}=13\right)$, zamirler açısından ortaya çıkan artış istatistiksel olarak anlamlı değildir $\left(\mathrm{z}_{\text {zamir }}=.53 \mathrm{p}>.05 ; \mathrm{N}=13\right)$.

Tablo 2 'de ise kontrol grubundaki çocukların her bir sözcük grubuna ait ön-test ve son-test sonuçlarına ilişkin betimsel bulguları ve analizler verilmiştir.

Tablo 2. Kontrol Grubundaki Çocukların Sözcük Türlerini Kullanımlarına İlişkin Betimsel Bulgular ve Wilcoxon Işsaretli Stralar Testi Sonuçları

\section{Kontrol Grubu}

\begin{tabular}{l|cccc|cccc|cr}
\hline \multirow{2}{*}{ Sözcük Türleri } & \multicolumn{4}{|c|}{ Ön-Test } & \multicolumn{4}{c|}{ Son-Test } & \multicolumn{2}{c}{ Wilcoxon } \\
\cline { 2 - 13 } & $\mathrm{X}$ & $\mathrm{Sd}$ & Max. & Min. & $\mathrm{X}$ & $\mathrm{Sd}$ & Max. & Min. & $\mathrm{Z}$ & $\mathrm{P}$ \\
\hline İsim & 15.92 & 9.32 & 37 & 3 & 21 & 16.34 & 58 & 6 & 1.26 & .208 \\
\hline Fiil & 13.23 & 4.57 & 24 & 9 & 19.62 & 16.71 & 72 & 7 & 1.15 & .248 \\
\hline Fiilimsi & 2.15 & 2.85 & 9 & 0 & 3.31 & 5.65 & 20 & 0 & .36 & .720 \\
\hline Zamir & 3.92 & 3.01 & 11 & 0 & 5.85 & 7.72 & 26 & 0 & .14 & .888 \\
\hline Sıfat & 3.46 & 4.61 & 14 & 0 & 4.62 & 5.30 & 19 & 0 & 1.15 & .126 \\
\hline Zarf & 5.77 & 4.51 & 16 & 0 & 5.15 & 3.74 & 10 & 0 & .27 & .789 \\
\hline Bağlaç & 3.31 & 3.01 & 10 & 0 & 6.46 & 8.50 & 32 & 0 & 1.16 & .245 \\
\hline
\end{tabular}


Tablo 2'de, okul öncesi eğitim programları çerçevesinde Türkçe etkinliğinin yürütüldüğü kontrol grubundaki çocukların, ön-test ve son-test puan ortalamaları incelendiğinde, sözcük türleri açısından çocukların son-test puan ortalamalarında bir artı̧̧ olduğu belirlenmiştir. Ön-testlerde kontrol grubundaki çocuklar anlattıkları hikâyelerde ortalama olarak 15.92 isim, 13.23 fiil, 2.15 fiilimsi, 3.92 zamir, 3.46 sifat, 5.77 zarf ve 3.31 bağlaca yer verirken, son-testlerde sirasıyla 21 isim, 19.62 fiil, 3.31 fiilimsi, 5.85 zamir, 4.62 sifat, 5.15 zarf ve 6.46 bağlaca yer vermişlerdir.

Ancak yapılan Wilcoxon İşaretli Sıralar testi sonucunda kontrol grubundaki çocukların ön test ve son test ortalamalarındaki bu artışlar, her bir sözcük türü açısından istatistiksel olarak anlamlı bulunmamıştır $\left(\mathrm{z}_{\text {isim }}=1.26 ; \mathrm{z}_{\text {fiil }}=1.15 ; \mathrm{z}_{\text {filimsi }}=.72 ; \mathrm{z}_{\text {zamir }}=.88 ; \mathrm{z}_{\text {strat }}=.13 ; \mathrm{z}_{\text {zarf }}=.79 ; \mathrm{z}_{\text {bağlac }}=.25 ; \mathrm{p}>.05\right.$ ; $\mathrm{N}=13$ ).

Deney ve kontrol gruplarındaki çocukların her bir sözcük türüne ilişkin ön-test ve son-test ortalama puanları arasındaki değişimin anlamlı olup olmadığına ise, Mann Whitney U- Testi ile bakılmıştır. Elde edilen verilere ilişkin Mann Whitney U-testi sonuçları Tablo 3’te sunulmuştur.

Tablo 3. Deney ve Kontrol Gruplarındaki Çocukların Sözcük Türlerini Kullanımlarına İlişkin Fark Puanlarının Mann Whitney U-testi Sonuçları

\begin{tabular}{|c|c|c|c|c|c|}
\hline Sözcük Türleri & Grup & Sura Ortalaması & Sira Toplamı & $\mathbf{U}$ & $\mathbf{P}$ \\
\hline \multirow[t]{2}{*}{ İsim } & Deney & 17.19 & 223.50 & \multirow{2}{*}{36.50} & \multirow{2}{*}{.012} \\
\hline & Kontrol & 9.81 & 127.50 & & \\
\hline \multirow[t]{2}{*}{ Fiil } & Deney & 17.23 & 224.00 & \multirow{2}{*}{36.00} & \multirow{2}{*}{.012} \\
\hline & Kontrol & 9.77 & 127.00 & & \\
\hline \multirow[t]{2}{*}{ Fiilimsi } & Deney & 16.23 & 211.00 & \multirow{2}{*}{49.00} & \multirow{2}{*}{.072} \\
\hline & Kontrol & 10.77 & 140.00 & & \\
\hline \multirow[t]{2}{*}{ Zamir } & Deney & 13.81 & 179.50 & \multirow{2}{*}{80.50} & \multirow{2}{*}{.840} \\
\hline & Kontrol & 13.19 & 171.50 & & \\
\hline \multirow[t]{2}{*}{ Sifat } & Deney & 16.42 & 213.50 & \multirow{2}{*}{46.50} & \multirow{2}{*}{.050} \\
\hline & Kontrol & 10.58 & 137.50 & & \\
\hline \multirow[t]{2}{*}{ Zarf } & Deney & 18.27 & 237.50 & \multirow[b]{2}{*}{22.50} & \multirow{2}{*}{.001} \\
\hline & Kontrol & 8.73 & 113.50 & & \\
\hline \multirow[t]{2}{*}{ Bağlaç } & Deney & 16.69 & 217.00 & \multirow{2}{*}{43.00} & \multirow{2}{*}{.034} \\
\hline & Kontrol & 10.31 & 134.00 & & \\
\hline
\end{tabular}

Tablo 3 incelendiğinde, deney grubundaki çocukların isim $(U=36,50 ; P<, 05)$, fiil $(U=36,00$; $\mathrm{P}<, 05)$, zarf $(\mathrm{U}=22,50 ; \mathrm{P}<, 05)$ ve bağlaç $(\mathrm{U}=43,00 ; \mathrm{P}<, 05)$ sözcük türlerinden elde ettikleri ön-test - son-test fark puanlarıyla kontrol grubundaki çocukların fark puanları arasında anlamlı bir farklılık olduğu bulunmuştur. Ancak fiilimsi ( $U=49,00 ; \mathrm{P}>, 05)$, zamir $(\mathrm{U}=80,50 ; \mathrm{P}>, 05)$ ve sifat $(\mathrm{U}=46,50$; $\mathrm{P}>$,05) sözcük türlerinden elde ettikleri fark puanları arasında anlamlı bir farklılık görülmemiştir.

Sözcük türlerine ilişkin olarak elde edilen bulgular değerlendirildiğinde, deney grubundaki çocukların ön-test ortalamalarının kontrol grubundaki çocuklara oranla daha düşük olmasına karşı, son-testlerden elde edilen bulgular göstermektedir ki hikâye temelli yaratıcı drama etkinlikleri sonrasında deney grubundaki çocuklar kontrol grubundaki çocuklara göre sözcük türlerini kullanım ortalamasında öne geçmiştir. Bu durum, deney grubuna uygulanan hikâye kitaplarından yola çıkılarak hazırlanan yaratıcı drama etkinliklerinin 4 yaş grubu çocuklarının sözcük türü kullanımında önemli bir etkiye sahip olduğunu göstermektedir. 


\section{Kullanılan Toplam Cümle Sayısı, Sözcük Sayısı ve Bir Cümlede Kullanılan Ortalama Sözcük Sayısına İlişkin Bulgular}

Çocuklar tarafindan oluşturulan hikâyelerdeki dil örnekleri, kurulan toplam cümle sayısı, sözcük sayısı, cümle sayısı ve bir cümlede kullanılan ortalama sözcük sayıları açısından analiz edilmiştir. Ek 1.' de deney ve kontrol gruplarından ikişer çocuğun ön-test ve son-test dil örnekleri sunulmuştur.

Deney (Tablo 4) ve kontrol (Tablo 5) grubundaki çocukların kullandıkları cümle sayısı, sözcük sayısı ve cümledeki ortalama sözcük sayısına ilişkin bulgular ise aşağıda sunulmuştur.

Tablo 4. Deney Grubundaki Çocukların Kullandıkları Cümle Sayısı, Sözcük Sayısı ve Cümledeki Ortalama Sözcük Sayısına İlişkin Sonuçlar

\begin{tabular}{l|cccc|ccccc|cc}
\hline \multicolumn{10}{c|}{ Ön-Test } & \multicolumn{1}{c|}{ Son-Test } & \multicolumn{2}{c}{ Wilcoxon } \\
\cline { 2 - 14 } & $\mathrm{X}$ & $\mathrm{Sd}$ & Max. & Min. & $\mathrm{X}$ & $\mathrm{Sd}$ & Max. & Min. & $\mathrm{Z}$ & $\mathrm{P}$ \\
\hline Cümle Sayısı & 11.85 & 4.85 & 26 & 8 & 19.39 & 7.07 & 34 & 8 & 3.08 & .002 \\
\hline Sözcük Sayısı & 38.38 & 29.68 & 123 & 13 & 91.77 & 51.57 & 190 & 22 & 3.11 & .002 \\
\hline $\begin{array}{l}\text { Cümledeki Ortalama } \\
\text { Sözcük Sayısı }\end{array}$ & 2.98 & .99 & 4.73 & 1.30 & 4.52 & 1.53 & 7.60 & 2.68 & 3.18 & .001 \\
\hline
\end{tabular}

Tablo 4 incelendiğinde, hikâye temelli yaratıcı drama etkinliklerinin yapıldı ̆̆ı deney grubunda yer alan çocukların öykü anlatırken kullandıkları toplam cümle sayısı, toplam sözcük sayısı ve bir cümlede kullandıkları ortalama sözcük sayısı bakımından son-test puan ortalamalarında ön-test puan ortalamalarına oranla önemli bir artış olduğu görülmüştür. Bu artışların anlamlılığını test etmek için yapılan Wilcoxon İşaretli Sıralar testi sonucunda bu artışların istatistiksel olarak anlamlı olduğu saptanmıştır $\left(\mathrm{z}_{\text {cümle sayısı }}=3.08 ; \mathrm{z}_{\text {sözcük sayısı }}=3.11 \mathrm{ve} \mathrm{z}_{\text {cümledeki ortalama sözcük }}=3.18 ; \mathrm{p}<.05 ; \mathrm{N}=13\right.$ ).

Türkçe etkinliklerinin uygulandığı kontrol grubundaki çocuklara ilişkin elde edilen betimsel bulgular ise Tablo 5' te sunulmuştur.

Tablo 5. Kontrol Grubundaki Çocukların Kullandıkları Cümle Sayısı, Sözcük Sayısı ve Cümledeki Ortalama Sözcük Sayısına İlişkin Sonuçlar

\begin{tabular}{|c|c|c|c|c|c|c|c|c|c|c|}
\hline \multicolumn{11}{|c|}{ Kontrol Grubu } \\
\hline & \multicolumn{4}{|c|}{ Ön-Test } & \multicolumn{4}{|c|}{ Son-Test } & \multicolumn{2}{|c|}{ Wilcoxon } \\
\hline & X & $\mathrm{Sd}$ & Max. & Min. & X & $\mathrm{Sd}$ & Max. & Min. & Z & $\mathrm{P}$ \\
\hline Cümle Sayısı & 13 & 3.76 & 23 & 9 & 16.23 & 8.68 & 40 & 7 & .98 & .326 \\
\hline Sözcük Sayısı & 50.77 & 29.03 & 129 & 15 & 67.16 & 56.84 & 221 & 15 & 1.20 & .230 \\
\hline $\begin{array}{l}\text { Cümledeki Ortalama } \\
\text { Sözcük Sayısı }\end{array}$ & 3.73 & 1.23 & 5.60 & 1.50 & 3.88 & 1.34 & 6.80 & 2.10 & 1.71 & .087 \\
\hline
\end{tabular}

Tablo 5’te görüldüğü gibi, kontrol grubunda yer alan çocuklarda da ön test puan ortalamalarına oranla cümle sayıs1, sözcük sayısı ve cümledeki ortalama sözcük sayısı açısından son- test puan ortalamalarında bir artış görülmektedir. Ancak yapılan analizler sonucunda kontrol grubunda gerçekleşen bu artışın, istatistiksel olarak anlamlı olmadığı saptanmıştır $\left(\mathrm{z}_{\text {cümle sayısı }}=.98 ; \mathrm{z}_{\text {sözcük sayısı }}=\right.$ 1.20 ve $\left.\mathrm{z}_{\text {cümledeki ortalama sözcük }}=0.87 ; \mathrm{p}>.05 ; \mathrm{N}=13\right)$. 
Kullanılan toplam cümle sayısı, sözcük sayısı ve bir cümlede kullanılan ortalama sözcük sayılarının öntest - sontest fark puanları açısından gruplar arasında herhangi bir farklı1ık meydana getirip getirmediğini sınamak için Mann Whitney U- Testi gerçekleştirilmiş ve elde edilen Mann Whitney U-testi sonuçları Tablo 6' da sunulmuştur.

Tablo 6. Toplam Sözcük Sayısı, Cümle Sayısı Ve Bir Cümlede Kullanılan Ortalama Sözcük Sayılarının Öntest - Sontest Fark Puanlarına İlişkin Mann Whitney U-testi Sonuçları

\begin{tabular}{|c|c|c|c|c|c|}
\hline & Grup & Sira Ortalaması & Sira Toplamı & $\mathbf{U}$ & $\mathbf{P}$ \\
\hline \multirow{2}{*}{ Cümle Sayısı } & Deney & 16,73 & 217,50 & \multirow{2}{*}{42,50} & \multirow{2}{*}{, 031} \\
\hline & Kontrol & 10,27 & 133,50 & & \\
\hline \multirow{2}{*}{ Sözcük Sayısı } & Deney & 17,85 & 232,00 & \multirow{2}{*}{28,00} & \multirow{2}{*}{, 004} \\
\hline & Kontrol & 9,15 & 119,00 & & \\
\hline \multirow{2}{*}{$\begin{array}{l}\text { Cümledeki } \\
\text { Ortalama Sözcük }\end{array}$} & Deney & 18,54 & 241,00 & \multirow{2}{*}{19,00} & \multirow[b]{2}{*}{, 000} \\
\hline & Kontrol & 8,46 & 110,00 & & \\
\hline
\end{tabular}

Tablo 6 incelendiğinde, deney grubunda yer alan çocukların cümle sayısı ( $U=42,50 ; P<, 05)$, sözcük sayısı ( $U=28,00 ; P<, 05)$ ve cümledeki ortalama sözcük sayısına $(U=19,00 ; P<, 05)$, ilişkin öntest - son-test fark puanları açısından kontrol grubundan anlamlı olarak farklılaştığı görülmektedir. Tablo 6'da yer alan analiz bulguları incelendiğinde, hikâye temelli yaratıcı drama etkinlikleri sonucunda deney grubu lehine anlamlı düzeyde bir artışın meydana geldiği söylenebilir.

Elde edilen bulgular ve yapılan analizler ışığında, hikâye temelli yaratıcı drama etkinliklerinin dört yaş çocuklarının kullandıkları toplam cümle sayısı, sözcük sayısı ve bir cümlede yer alan ortalama sözcük sayısını arttırdı̆̆ı söylenebilir.

\section{Tartışma}

$\mathrm{Bu}$ çalışmanın sonuçları, hikâye temelli yaratıcı drama etkinliklerinin dört yaş grubu çocukların ifade edici dil gelişimlerine önemli etkileri olduğunu ortaya koymuştur. Araştırma sonucunda, hikâye temelli yaratıcı drama etkinliklerinin dört yaş çocuklarının isim, fiil, fiilimsi, sıfat, zarf ve bağlaç-kullanımlarında anlamlı bir artışa neden olduğu saptanmıştır. Ayrıca hikâye temelli yaratıcı drama etkinlikleri çocukların kullandıkları toplam cümle sayısı, sözcük sayısı ve bir cümlede yer alan ortalama sözcük sayısını da artırmıştır.

Alan yazın incelendiğinde, bu çalışmanın sonuçlarının daha önce yapılan çalışmalarla birbirini destekler nitelikte benzer sonuçlar gösterdiği saptanmıştır. Aktaş Arnas, Cömertpay ve Sofu (2007), altı yaş grubu çocuklarla yaptıkları bir çalışmada yaratıcı drama etkinliklerinin altı yaş çocukların, isim, sıfat, fiilimsi (ulaç-ortaç) ve bağlaç kullanımlarında anlamlı bir artışa neden olduğunu saptamışlardır. Yine aynı çalışmada yaratıcı drama etkinliklerinin çocukların kullandıkları toplam sözcük sayısında, kullanılan ortalama sözcük sayısında ve bir cümlede kullanılan toplam sözcük sayısında anlamlı bir farklılık yarattığı saptanmıştır. Bu açıdan yapılan bu çalışma dört yaş çocukları için de yaratıcı drama etkinliklerinin etkili olduğunu göstermektedir. Cömertpay (2006) tarafindan beş-altı yaş grubu çocuklarla yapılan bir başka çalışmada da uygulanan yaratıcı drama etkinliklerinin, çocukların isim ve sıfat kullanımlarında istatistiksel olarak anlamlı bir farklığa neden olduğu sonucuna varılmıştır. 
Ayrıca, Uyar (1995)'ın yürüttüğü çalışmada, beş-altı yaş çocuklarına uygulanan drama programının, çocukların alıcı dil, ifade edici dil ve sözcük dağarcığı gelişimlerini anlamlı etkilediği ve çocukların dili kullanma becerilerini geliştirdiği sonucuna varmıştır. Solmaz (1997), altı yaş grubu çocuklarıyla yaptığı drama etkinliklerinin, çocukların alıcı ve ifade edici dil becerilerini olumlu etkilediğini bulmuştur. Çakır (2008), okul öncesi Türkçe etkinliklerinde yaratıcı drama yönteminin kullanılmasının çocukların görüp izlediğini anlama ve anlatma becerileri açısından etkili olduğunu belirtmiştir. Koç (2009) çalışmasında, altı yaş grubu okul öncesi çocukların Türkçe etkinlikleri sırasında uygulanan yaratıcı drama etkinliklerinin çocukların dil gelişimleri üzerinde anlamlı bir etkisi olduğunu ve yaratıcı dramanın çocukların dil edinimine ve sözcük dağarcıklarını etkin bir biçimde kullanmalarına yardımcı olduğunu bulmuştur.

\section{Sonuç ve Öneriler}

Araştırma sonucunda, hikâye temelli yaratıcı drama etkinliklerinin dört yaş çocuklarının isim, fiil, zarf, bağlaç kullanımlarında anlamlı bir artışa neden olduğu ve çocukların kullandıkları toplam cümle sayısı, sözcük sayısı ve bir cümlede yer alan ortalama sözcük sayısını da arttırdığ1 görülmüştür. $\mathrm{Bu}$ çalışmanın sonuçları yaratıcı drama alanına önemli bir katkı sağlamaktadır. Çalışmadan elde edilen sonuçlar, hikâye temelli yaratıcı drama etkinliklerinin çocukların ifade edici dil gelişimlerine önemli etkileri olduğunu göstermiştir. Bu nedenle okul öncesinde ifade edici dil gelişimin desteklemek için hikâye temelli yaratıcı drama etkinliklerinin öğrenme süreçlerinde kullanılması önerilebilir.

Hikâye temelli yaratıcı drama etkinliklerinin çocukların ifade edici dil gelişimlerine olumlu katkılarının olduğunu ortaya koyan bu çalışma bazı sınırlılıklar da içermektedir. Çocukların dil gelişimlerine etki eden tüm faktörleri kontrol altına almak ve ölçmek zordur. Drama etkinliklerinin dışında çocukların sınıf içinde ve sınıf dışındaki etkileşimleri de küçük çocukların dil gelişimlerinde etkili olabilir. Bu çalışmada bu gibi değişkenlere yer verilememiştir. Planlanacak daha sonraki çalışmalarda küçük çocukların dil gelişimlerinde etkili olabileceği düşünülen diğer faktörler de belirlenerek incelenebilir. Bunun yanı sıra bu çalışma küçük bir çalışma grubu üzerinde yürütülmüştür. Bu nedenle sonuçlar genellenemez. Ancak çalışma, küçük yaş grubu çocuklarda yaratıcı drama ve dil gelişimine ilişkin süregelen tartışmalara ve daha sonra bu konuda yapılacak çalışmalara ışık tutabilir. Gelecek çalışmalarda örneklem ve yaş grubu genişletilebilir. Farklı ölçme araçlarıyla çocukların dil gelişimleri ölçülebilir. Yapılan çalışmanın sonuçlarına dayanarak okul öncesi dönemde çocukların dil gelişimlerine katkı sağlamak için Türkçe etkinliklerinde hikâye kitaplarını sadece okunması yerine yaratıcı drama yöntemiyle bütünleştirilerek uygulanması önerilebilir. Sonuç olarak bu çalışma, yaratıcı drama ve dil gelişimi alanları hakkında olumlu ipuçları vermesi açısından önemlidir.

\section{Kaynakça}

Adıgüzel, H. Ö. (1994). Eğitimde yeni yöntem ve disiplin: yaratıcı drama, 1. Eğitim Bilimleri Kongresi Bildiri Kitabl, Çukurova Üniversitesi Eğitim Bilimleri Fakültesi, Cilt 2, 522-533.

Aktaş Arnas, Y. , Cömertpay, B., ve Sofu, H. (2007). Altı yaş grubu çocukların dil kullanımına yaratııı dramanın etkisi. Yaratıcı Drama Dergisi, Cilt 1, Sayı 3-4, 7-26.

Aral, N., Gülen, B., Alisinanoğlu, F., Aktaş, Y., Başar, F. ve Köksal, A. (1997). Beş-altı yaş grubu çocuklarda yaratıcı drama eğitiminin alıcı dil gelişimine etkisi. Türkiye Okul Öncesi Eğitimini Geliştirme Derneği, Okul Öncesi Eğitim Sempozyumu: Okul Öncesi Eğitimde Yeni Yaklaşımlar. Ankara: Ankara Üniversitesi Basımevi, 140-152. 
Baldwin, P., ve Hendy, L. (2008). The drama book. London: Collins Educational.

Baştürk, M. (2013). Anadil edinimi. Ankara: Pegema Yayıncılık.

Büyüköztürk, Ş. (2012). Sosyal bilimler için veri analizi el kitabı, (16. Baskı). Ankara: Pegema Yayıncılık.

Cook, J., ve Cook, G. (2005). Child development: principles and perspectives. Boston: Pearson Education Inc.

Cömertpay, B. (2006). Dramanın 5-6 yaş grubu çocukların dil edinimine etkisi. Yayımlanmamış yüksek lisans tezi. Çukurova Üniversitesi Sosyal Bilimler Enstitüsü, Adana.

Çakır, B. (2008). Anasınıfı Türkçe dil etkinliklerinde yaratıcı drama yönteminin etkililiği. Yayımlanmamış yüksek lisans tezi. Ondokuz Mayıs Üniversitesi Sosyal Bilimler Enstitüsü, Samsun.

Elley, W. B. (1989). Vocabulary acquisition from listening to stories. Reading Research Quarterly, Vol.24(2), 174-187.

Ervin Tripp, S. M. (1991). Play in language development. In Scales, B., Almy, A., Almy, M., Nicolopoulou, A., ve Ervin-Tripp, S. M. (Eds), Play and the social context of development in early care and education. New York: Columbia Teachers College, 84-98.

Furman, L. (2000). In support of drama in early childhood education, again. Early Childhood Education Journal, 27(3), 173-178.

Guasti, M. T. (2002). Language acquisition: The growth of grammar. MIT Press.

Güven, N. ve Bal S. (2000). Dil gelişimi ve eğitim. 0-6 yaş dönemindeki çocuklar için destekleyici etkinlikler, İstanbul: Epsilon Yayınları.

Hoff, E.,(2005). Language development. Belmont, CA: Wadsworth/Thomson Learning.

Isbell, R., Sobol, J., Lindauer, L., ve Lowrance, A. (2004). The effects of storytelling and story reading on the oral language complexity and story comprehension of young children. Early Childhood Education Journal, 32(3), 157-163.

Kardash, C. A. M. ve Wright, L. (1987). Does creative drama benefit elementary school students: a meta-analysis._Youth Theatre Journal, 1(3), 11-18.

Kelin, D. A. II, (2007). The perspective from within: Drama and children's literature. Early Childhood Education Journal, 35(3), 277-284.

Koç, N. (2009). Eğitimde dramanın altı yaş çocuklarının dil gelişimleri üzerindeki etkisi. Yayımlanmamış yüksek lisans tezi. Uludağ Üniversitesi Sosyal Bilimler Enstitüsü, Bursa.

Laurin, S. (2010). The effect of story drama on children's writing skills (Order No. MR67265). Available from ProQuest Dissertations \& Theses Full Text. (807456545). Retrieved from http://search.proquest.com/ docview/807456545? accountid $=15725$.

Macrory, G. (2010). Language development: what do early years practitioners need to know?. Early Years: An International Journal of Research and Development, 21(1), 33-40.

Mages, W. K. (2008). Does creative drama promote language development in early childhood? A review of the methods and measures employed in the empirical literature, Review of Educational Research, 78, 124-152.

Maley, A ve Duff, A. (2006). Drama techniques: A resource book of communication activities for language teachers. (3rd. edition). Cambridge: Cambridge University Press.

McCaslin, N. (2006). Creative drama in the classroom and beyond. (8th Edition). Boston: Pearson/Allyn and Bacon.

MEB, (2013), Okul Öncesi Eğitim Programı, Milli Eğitim Bakanlığı Temel Eğitim Genel Müdürlüğü, Ankara.

Niedermeyer, F. C., ve Oliver, L. (1972). The development of young children's dramatic and public speaking skills. The Elementary School Journal, 95-100.

O'Neill, B. E. (2008). Storytelling and creative drama: A dynamic approach to inclusive early childhood education (Order No. 3348584). Available from ProQuest Dissertations \& Theses Full Text. (304626940). Retrieved from http://search.proquest.com/docview/304626940?accountid=15725 
Podlozny, A. (2000). Strengthening verbal skills through the use of classroom drama: A clear link. Journal of Aesthetic Education, 239-275.

Riley, J. ve Reedy, D. (2003). Communication, language and literacy: learning through speaking and listening, reading and writing. Jeni Riley (Ed.), Learning in the early years a guide for teachers of children 3-7. Paul Chapman Publishing.

Solmaz, F. (1997). 6 yaş grubu çocukların alıcı ve ifade edici dil gelişimine yaratıcı drama eğitiminin etkisi. Yayımlanmamış yüksek lisans tezi., Gazi Üniversitesi Sosyal Bilimler Enstitüsü, Ankara.

Szecsi T. (2008) Teaching strategies: creative drama in preschool curriculum: teaching strategies implemented in Hungary, Childhood Education, 85:2, 120-124.

Umek, L. M., Fekonja, U., Kranjc, S., ve Musek, P. L. (2003). The impact of reading children's literatüre on language development in the preschool child. European Early Childhood Education Research Journal, 11(1), 125-135.

Uyar, N., (1995) Anaokuluna devam eden 60-72 aylık çocuklara destekleyici olarak uygulanan eğitimde drama programının çocukların dil gelişimine etkisinin incelenmesi. Yayınlanmamış yüksek lisans tezi. Hacettepe Üniversitesi Sosyal Bilimler Enstitüsü, Ankara.

Yazgan İnanç, B., Bilgin, M., ve Atıcı Kılıç, M., (2008). Çocuk ve ergen gelişimi. Ankara: Pegem Akademi Yayıncilik.

Weisberg, D. S., Zosh, J. M., Hirsh-Pasek, K., ve Golinkoff, R. M. (2013). Talking it up: An analysis of the role of play in language development. American Journal of Play, 6(1), 39 - 54.

Zafeiriadou, N. (2009). Drama in language teaching. Issue 23, 4-9. 
Ek 1. Deney ve Kontrol Grubundaki Çocukların Ön-test ve Son-test Öykü Anlatım Örnekleri

\begin{tabular}{|c|c|}
\hline ÖN TEST ÖYKÜLERİ & SON TEST ÖYKÜLERİ \\
\hline $\begin{array}{l}\text { "Terlik var. Saat çalmıştı. Ayı kaçacak. Bunu } \\
\text { yakalamak için kaçmış. Tavşan gelmiş. } \\
\text { Kaplumbağaları çağırmış. Kurbağa suyun içinden } \\
\text { onu 1sırmaya çalışmış. Suyun içine düşmüş. } \\
\text { Kurtulmuş. Annesi ona vurmuş.”D1 }\end{array}$ & $\begin{array}{l}\text { "Bu, kapıdan gidiyormuş. Sonra da annesi uyurken } \\
\text { kapıdan gitmiş. Sonra da bir bakmış annesi yok. Sonra } \\
\text { bir şey olmuş, bakamamış. O kaçtığından annesi } \\
\text { bulamamış onu. Kaplumbağaya takılıp ayı düşmüş } \\
\text { yere. Bir bakmış, tavşan içeri girmeye çalışıyor. Sonra } \\
\text { annesi onu bulamadığı için buraya bakmış. Sonra } \\
\text { düşmüşs. Sonra annesi bulamamış. Sonra suya düşmüş, } \\
\text { ağlamış. Sudan çıkınca bir şey bulmuş. Annesine } \\
\text { gitmeyi denemiş ama gidememiş. En sonunda annesi } \\
\text { onu bulmuş."D1 }\end{array}$ \\
\hline $\begin{array}{l}\text { "Bu ayı uyuyor. Bu ayı kapıyı açıyor. Ayı koştu. Ayı } \\
\text { baktı. ayı kaplumbağaya baktı. Ayı kurbağaya baktı. } \\
\text { Ayı suya düştü. Ayı baktı. Ayı ağlıyor.” D11 }\end{array}$ & $\begin{array}{l}\text { "Babasının yanına gelmiş. Sonra açmış kapıyı. Sonra } \\
\text { da babasına bakmış. Sonra da ayı içeri girmiş. Ayı dışarı } \\
\text { çımış. Bir ayı gelmiş. Sonra da ona bakmış. Sonra da } \\
\text { uçmuş. Bir ayı gelmiş arı da gelmiş. Tavşan da evine } \\
\text { gidiyormuş. Bir ayı gelmiş. Sonra da kaplumbağa } \\
\text { gelmiş. Sonra da onlara bakıyor. Sonra onlar da ayıya } \\
\text { bakıyor. Ayı kurbağalara bakmış. Arı da kurbağalara } \\
\text { bakmış, dönmüşler birbirlerine. Sonra da bunlar } \\
\text { böyle yapmış. Ayı suya düşmüş. Ayı yere bakmış. Ayı } \\
\text { annesine gitmiş ağlamış." D11 }\end{array}$ \\
\hline $\begin{array}{l}\text { "Uyuyor. Büyüyor. Koşuyor. Bir şey arıyor. Tavşana } \\
\text { bakıor. Kaplumbağaları izliyor. Kurbağaları } \\
\text { izliyor. Ağlıyor. Şaşırmış. Ağlıyor.”K6 }\end{array}$ & $\begin{array}{l}\text { "Uyuyor ve odasına giriyor. Koşuyor. Tavşana bakıyor. } \\
\text { Kaplumbağalara bakıyor. Kurbağalara bakıyor. Eli } \\
\text { kanamış. Eve gelmiş."K6 }\end{array}$ \\
\hline $\begin{array}{l}\text { "Ayıcı̆̆ın uykusu gelmişti. Sonra yatmış. Her şey } \\
\text { uyumuş. Sonra kapııı açmış. Koşmuş ve de burada } \\
\text { üzülmüş. Bu üzülmemiş. Bu da üzülmemiş. Ayı } \\
\text { yine üzülmüş. Kurbağalar vırak vırak demiş. Denize } \\
\text { düşmüş. Sonra yine üzülmüş. Annesi, ne kadar } \\
\text { yaramazsın sen... Sonra da dışarı çıkmışlar."K26 }\end{array}$ & $\begin{array}{l}\text { "Anne uyuyormuş. Çocuk da uyumuyormuş. Ayı } \\
\text { kaybolmuş. Sonra annesini bulmuş. Annesi de ağlamış, } \\
\text { üzülmüş. Sonra tavşan onunla konuşmaya çalışmış. Ayı } \\
\text { kaplumbağaların yanına gitmiş. İki tane kaplumbağa } \\
\text { varmış. Kurbağanın yanına gitmiş. Sonra kuş bulmuş. } \\
\text { Annesini üzmüş, kaybolmuş. Sonra suya düşmüş. } \\
\text { Üzülmüş. Ayı kaybolmuş. Annesini bulamamış. Bunlar } \\
\text { meyveler. Küçük ayı annesini bulmuş.” K26 }\end{array}$ \\
\hline
\end{tabular}

Ek 2. Deney Grubunda Yaratıcı Drama Planları İçin Kullanılan Hikâye Kitapları

1. “Benim Minik Kırmız Balığım” Tudem Yayıncılık

2. “Kırmızı Fil’i Gördünüz mü?” Kök Yayıncılık

3. "Devekuşu Dudu" Sev-Yay

4. "Lütfen de, Hande!” Bilge Kültür Sanat

5. "Karıncanın Kardeşi ”Tudem yayıncılık

6. “Kedi De Kedi” Yapı Kredi Yayınları

7. "Çağlar Tanımadığı İnsanlarla Bir Yere Gitmez” Türkiye İş Bankası Kültür Yayınları

8. “Suda Neler Olmuş ?" Kök yayıncılık

9. "Herkes Kızar" - Goa Junior

10. “Sadece Mor Rengi Seven Kral? ” Kök yayıncılık 
Ek 3. Atölye Planı Örneği (On Üçüncü Oturum)

Konu: Dil Becerisi

Grup: 4 yaş

Süre: 50 dakika

Mekan: Sinıf

Yöntem-Teknik: (Yaratıı Drama) -Tüm grup doğaçlama - Rol Oynama-Donuk İmge-Öğretmen Rolde

Araç-Gereç: Resimli Kitap (“Karıncanın Kardeşi ” Tudem yayıncılık), Turuncu Fon kartonundan yapılmış gaga.

\section{Kazanımlar:}

Dil Alanı

- Belli bir konuda konuşmayı başlatır.

- Belli bir konuda konuşmayı sürdürür.

- Duygu, düşünce ve hayallerini söyler.

- $\quad$ Üstlendiği role uygun konuşur.

\section{Süreç}

\section{A- Hazırlık-Isınma}

Lider, çocuklara bazı hayvan isimleri (sırasıyla, fil, aslan, köpek, kedi, tavşan, kurbağa, salyangoz, örümcek, karınca) söyler ve onlar gibi yürümelerini ister. Çocukların uygun öykünmeleri yapmalarını bekler. Daha sonra çocuklardan yere oturmalarını ister ve "Karıcanın Kardeşi" adlı hikayeyi okumaya başlar.

"Bir zamanlar, bir küçük karınca vardı. Annesi ve babasıyla birlikte mutlu mutlu yaşardı. İste bu karınca bir sabah uyanınca bir yumurta bulmuştu yanı başında. Yumurta çatlayınca çıkıvermişti içinden minicik mini minnacık bir bebek karınca! Bir kardeşin oldu demişlerdi ona. Kardeşi olacağına keşke bir bisikleti olsaydl. O zaman imrenirdi ona bütün arkadaşları. Ya da el feneri mesela.. Bir sürü işe yarar pilli bir fener, düğmesine basarsın yanar, basarsın söner. Peki, bir kardeş neye yarar? Karıncanın kardeşi ne top oynayabilir, ne de koşabilirdi. Paytak paytak yürürdü ikide bir düşerdi. Kaybederdi her şeyi ama yine isterdi. İstediği olmaylnca o minicik karınca başlardı ağlamaya! Çıngırak gibiydi sesi. Evin neresinde olsa, mutlaka işitirdi annesi. Karınca ne yaparsa..-ben de! -beni de! - benim de! Karınca hangi oyuncağı eline alsa-Benim bu! Çiğnenmiş sakızın bile ..Yarısını bana ver! Karıncanın hayatı hiç de kolay değildi. Yine bir gün karınca kardeşiyle uğraşmaktan bıkınca "Anne sokağa çıkabilir mitim?”"dedi. Kardeşi bunu duyunca hemen "Ben de geleceğim!” diye bağırdı öteden. Karınca, "Anne lütfen gelmesin! Diye mızıldandı. Kendini tutmasa resmen ağlayacaktı. " Hiç olur mu öyle şey? Haydi tut elinden kardeşinin... Yalnız prup prup diye öten kurlangıç kuyruklu arı kuşuna dikkat edin. kırmızı bahçe hortumunun ötesine da sakın geçmeyin” Karıncalar bu mahalleye yeni taşınmışlardı. Sokaktaki arkadaşlarının hepsi de pek yamand. "Hadi gelin, esasl bir oyun biliyorum" dedi çekirge "Ama kırmı hortumun ötesinde." hemen kabul etti ötekiler, her zamanki gibi macera peşindeydiler. Korktu karıncanın kardeşi "Biz gitmeyelim! dedi, kardeşinin gözleri dolu dolu olunca," "Tamam oğlum ya, hemen ağlamaya başlama, gel hadi, sen de katıl oyuna. Bak senin görevin önemli, sen gözcü olacaksin, şuraya, musluğun üstüne çıkacaksın. Annem bu tarafa gelirse, bu düdüğ̈̈ öttürüp bizi uyaracaksin." Kardeşi oyunda önemli bir rol alacağına inandı. Sevinçle uzaklaşıp musluğun tepesine tırmandı. Bu sirada, prup prup, işte yakalandılar! Kırlangıç kuyruklu arı kuşu bu! Şimdi hepsini yutar!”

Lider hikâyeyi yarım bırakır ve çocuklara hikâyede hangi böceklerin olduğunu sorar. Daha sonra çocuklardan hikâyede geçen böceklerden hangi böcek olmak istediklerine karar vermelerini ve onun şeklini alarak donmalarını ister. Daha sonra lider her birinin yanına giderek hangi böcek olduklarını, neye benzediklerini, özelliklerini ve en sevdikleri şeyleri söylemelerini ister. 


\section{B- Canlandırma}

Ardından lider, "işte tüm böcekler bahçede birlikte oyun oynuyordu" der ve böcek rolündeki çocukların oyun oynamalarını bekler. Böcek rolündeki çocuklar oyun oynarken lider o sırada "Prup prup" der ve kartondan yaptı̆̆ı turuncu gagayı takarak böceklerin arasına kırlangıç kuyruklu arı kuşu olarak role girer. Birkaç tur attıktan sonra uzaklaşır ve rolden çıkar.

Lider alkış sesiyle tüm böceklerin oldukları yerde donmalarını ister. Sonra tek tek yanlarına giderek "Ne oldu?, Sence bundan sonra ne olacak?, Arı kuşu yine gelir mi? Kendin nasıl hissediyorsun? Ne yapmalıyız?" sorularını yöneltir. Ardından çocuklara "Şanslıydık arı kuşu bu defa bize zarar vermeden gitti, peki şimdi ne yapmalıyız?" sorusunu ortaya atar ve çocuklardan gelen cevapları dinler. "Ya tekrar gelirse?", "Şimdi ne yapmalıyız?", "Arı kuşu bir daha gelirse nasıl bir plan yapmalıyız" gibi ara sorularla çocukların çözüm üretmelerini bekler. Bir fikir üzerinde anlaştıktan sonra lider çocukların yanından uzaklaşır. Lider tekrar gagasını takar ve arı kuşu olarak böceklerin yanına gelir ve böceklerin karar verdikleri planı uygulamalarını bekler.

\section{C- Değerlendirme}

Lider çocuklara hikâyenin sonunu okur ve daha sonra çocuklara, "neler oldu?, neler yaptık?, nasıl hissetiniz kendinizi? Karınca ve kardeşi nerde hata yaptılar? Gibi sorular yöneltilir. Sonra çocuklara kağıt ve boya dağıtarak onlardan karınca ve arkadaşlarının resmini yapmasını ister. 